\title{
Effect of Sowing Dates and Foliar Application with Zinc on Production and Quality of Two Faba Bean (Vicia faba, L.) Varieties
}

\author{
Mahdy A.Y. and H.A. Ahmed \\ Dept. of Agron., Fac. of Agric., Al-Azhar Univ., Assiut, Egypt.
}

\begin{abstract}
Two field Experiments were conducted at the Experimental Farm of the Agriculture Research Center in Al-Azhar Univ. at Assiut, during 2016/17 and 2017/18 seasons to study the effect of three sowing dates $\left(10^{\text {th }}\right.$ October, $25^{\text {th }}$ October and $10^{\text {th }}$ November) and foliar application with zinc [0 (control), 30 and $60 \mathrm{ppm}$ ] on the production and quality of two varieties of faba bean (Misr-1 and Giza-40).

The obtained results showed that faba bean varieties exhibited significant differences in 100-seed weight; seed yield and straw yield/fad. and seeds protein percentage in both seasons, except seed yield/plant in the second season only. On other hand, number of branches/plant and number of pods/plant did not showed significant differences in both seasons. Also, sowing dates caused significant and gradual increases in all traits under study in both seasons. In generally, crop sown in 25- October produced the highest values of all mentioned characters in both growing seasons. Increasing the concentration zinc foliar of application from 0,30 and $60 \mathrm{ppm}$ caused significant and gradual increases in all studied characters, i.e. number of branches and of pods/plant, seed yield/plant, 100-seed weight as well as seed and straw yields/fad. Also, such treatment increased protein percentage of faba bean seeds. In general, the highest value of seed yield/ fad. and quality was obtained from sowing faba bean Misr-1 variety on the $25^{\text {th }}$ Oct. and zinc foliar application concentration of $60 \mathrm{ppm}$ under Assiut conditions.
\end{abstract}

Key words: Faba bean, sowing date, foliar application, zinc fertilizer.

\section{INTRODUCTION}

Faba bean (Viciafaba, L.) is the most important food legume in Egypt for human nutrition and improvement of soil characteristic. The importance of its seeds lies chiefly to its high protein content with high calories and nutritive value since it contains about $24 \%$ proteins and a source of carbohydrates. Bakheit et al. (2001) showed that, plant height, seed yield and 100-seed weight were significantly affected by faba bean cultivars (Giza-2, Giza-402, Giza-429 and Giza674). While numbers of branches and pods/plant and straw yield/fad. were not affected by cultivars. Khalil et al. (2004)indicated that Misr-1 cultivar surpassed Giza-40 cultivar in number of pods/plant, weight of seeds/plant, weight of 100 seeds (g), seed yield (ard./fad.), straw yield (ton/fad.) and seed protein percentage. However, seed phosphorus percentage did not significantly affected in both seasons. Sharaan et al. (2004) indicated that, the tested faba bean cultivars (Giza2, Giza-429, Giza-843 and Misr-1) showed significant differences for all studied characters (seed yield /plant, seed index, seed yield /fad. and protein percentage). Ahmed and El-Abagy (2007) showed that, faba bean cultivars were significantly differed in number of branches/plant, number of pods /plant, seed yield/plant, seed yield/fad. straw yield/ fad. and seeds protein\%. El-Bannaet al. (2009) found significant differences between the two faba bean cultivars in number of branches/plant, number of pods/plant, seed yield /plant, seed yield /fad. straw yield/fad. and seed protein content in both seasons. Hassan (2016)showed that, faba bean varieties exhibited significant differences in 100-seed weight; seed and straw yields/fad. and seeds protein percentage in both seasons, except seed yield/plant in the first season only. On other hand number of branches/plant and number of pods/plant did not showed significant differences in both seasons.

Sowing date is an important factor, which affects the timing and duration of the vegetative and reproductive stages. Faba bean sowing date varied among different locations. The variation in sowing date plays an important role in variation of faba bean yield and quality. Bakheit et al. (2001) revealed that, sowing date exerted a significant influence on all traits (seed yield /fad (ard.), seed yield / plant (g), weight of plant $(\mathrm{g})$, number of pods / plant and seed index (weight of 100 seeds (g)) under studies, except number of branches in newly reclaimed soil. Sharaan et al. (2004) indicated that, sowing dates showed significant differences for all studied characters (number of pods /plant, seed yield /plant, seed index, seed yield /fad. and protein percentage) except number of branches/plant in the first season. Alazaki and Al-Shebani (2012) showed that, sowing dates affected number of branches/plant, number of seeds /plant, pods weight / plant, straw weights/plant and seeds yield/plant in the two 
seasons. Abido and Seadh (2014) pointed that, sowing on $1^{\text {st }}$ November gave highest growth attributes, seed yield and its components and protein $\%$.

Zinc is one of the most important essential micronutrients required for optimum crop growth. It plays an important role in many biochemical reactions within plants. Zinc is important in the formation of the plant growth hormone auxins. Auxins are produced by shoot tips, and control cell division, leaf and shoot growth and fruit development (Mansour, 2014). Zinc is also needed by leaf cells to form the green leaf pigment chlorophyll. Also, zinc plays an essential role in plant physiology, where it actives some of enzymes such as dehydrogenises, pretenses, peptidases and phosphohydrolases. Zinc is a micronutrient needed in small amounts by crop plants, but its important in crop production increases in recent years (Fageria, 2009). Abd El-Monem et al. (2009) showed that, foliar application with zinc significantly increased number of pods/plant, weight of 100 seed and protein content. El-Gizawy and Mehasen (2009) indicated that, there were significant differences between foliar applications of zinc treatments in all traits studied (number of branches/plant, number of pods/plant, 100-seed weight, seed yield/plant, seed and straw yields/fad.) and seeds protein percentage in both seasons. Saad (2015) revealed that, foliar application with zinc to faba bean plants significantly increased growth characters (number of branches /plant) and yield components (seed yield / fad ( $\mathrm{kg}$ ), seed yield / plant (g), weight of plant $(\mathrm{g})$, number of pods / plant, number of seeds / plant and seed index (weight of 100 seeds $(\mathrm{g}))$ and protein content in both seasons.

The objective of the present work is to study the response of two faba bean varieties, Misr-1 and Giza- 40 to three sowing dates and application at three levels of zinc under Assiut Governorate conditions.

\section{MATERIALS AND METHODS}

Two field Experiments were conducted at the Agricultural Experimental Farm of the Agriculture Research Center in Al-Azhar Univ. at Assiut, during 2016/17 and 2017/18 seasons to study the effect of sowing dates and foliar with zinc on production and quality of two faba bean (Viciafaba,L.) varieties under Assiut Governorate conditions. Each experiment included 18 treatments which were the combinations of two faba bean varieties, three sowing dates and three levels of zinc.

\section{A- Faba bean varieties:}

1- Misr-1.

2- Giza- 40.

B- Sowing dates:

$1-10^{\text {th }}$ October.

2- $25^{\text {th }}$ October.

3- $10^{\text {th }}$ November.

C- Zinc levels:

1- Control (water).

2- $30 \mathrm{ppm}$.

3- $60 \mathrm{ppm}$.

Zinc levels were sprayed three times during the growth period (30, 50 and 70 days after sowing). Spraying was applied in early morning. All treatments were applied triple as foliar spray on plants using hand operated compressed air sprayer at the rate of 10 liters/plot.

The experimental design was randomized completed blocks in split-split plot arrangement with three replications. Faba bean varieties were assigned to the main plot, sowing dates were distributed randomly in the subplots and zinc levels were allocated to the sub -sub plots. The experimental unit comprised five ridges, each $3.5 \mathrm{~m}$ long and $0.6 \mathrm{~m}$ wide $\left(10.5 \mathrm{~m}^{2}\right.$ in area $=1 / 400$ /fad.). Seeds in a population of 140 thousand plants/fad. were sown on the two sides of ridges, in hills $20 \mathrm{~cm}$ apart and thinned to two plants/hill. The preceding summer crop was maize in both seasons. All other practices were uniformly applied as recommended for faba bean production in the region. The mechanical and chemical analyses of the experimental site are presented in Table (1).

Studied characters:-

A- Yield and yield components:

At harvest, samples of 10 plants were chosen randomly from the inner ridges and the following characters were recorded:

Table 1: The mechanical and chemical analysis of soil field experiments

\begin{tabular}{|c|c|c|c|c|c|}
\hline Mechanical analysis & $2016 / 17$ & $2017 / 18$ & Chemical analysis & 2016/17 & $2017 / 18$ \\
\hline Sand $(\%)$ & 25.80 & 25.50 & Organic matter (\%) & 0.94 & 1.02 \\
\hline Silt (\%) & 37.70 & 38.40 & Available N (ppm) & 74.44 & 76.50 \\
\hline Clay $(\%)$ & 36.50 & 36.10 & Available P(ppm) & 9.64 & 10.55 \\
\hline \multirow{4}{*}{ Soil texture } & \multirow{4}{*}{\multicolumn{2}{|c|}{ Clay loam }} & Available K (ppm) & 355.11 & 363.23 \\
\hline & & & pH (s.p. 65 ) & 7.73 & 7.99 \\
\hline & & & E.C. $\left(\right.$ ds. $\left.\mathrm{m}^{-1}\right)$ & 1.18 & 1.20 \\
\hline & & & Total $\mathrm{CaCo}_{3}(\%)$ & 2.84 & 2.61 \\
\hline
\end{tabular}


1- Number of branches / plant.

2- Number of pods / plant.

3- Seed yield /plant (g).

4- 100- seed weight (g):

5- Seed yield (ard./fad.) ( $\operatorname{ard} .=155 \mathrm{~kg})$.

6- Straw yield (ton/fad.). Seed and straw yields were recorded on the basis of all plants/ plot. The recorded values were used to estimate the corresponding values/ per fed.

\section{B- Chemical analysis:}

At harvesting, seed samples were ground and kept for chemical analysis.

Protein percentage:-

Total nitrogen content in seeds was estimated by using micro-kjeldahl method as described by A.O.A.C (1980) and percentage of protein was calculated by multiplying the nitrogen percentage by 6.25 .

\section{Statistical analysis:-}

Data were statistically analyzed according to Gomez and Gomez (1984) using the computer MSTAT-C statistical analysis package by Freed et al. (1989). The least significant differences (LSD) test at probability level of 0.05 was manually calculated to compare the differences among treatments means.

\section{RESULTS AND DISCUSSION}

A- Yield and yield components:1- Number of branches/plant.

It is quite clear from the results presented in Table (2) that the difference between the two studied varieties in number of branches/plant were not significant in 2016/17 and 2017/18 seasons. Similar results were obtained by Bakheit et al. (2001) and Hassan (2016).

The results presented in Table (2) revealed that the number of branches/plant was significantly affected by sowing dates in both seasons. The highest means of number of branches/plant (4.21 and 3.81) were obtained on account of sowing faba bean plants on $25^{\text {th }}$ Oct. in the first and the second seasons, respectively. However, the lowest one of this trait (2.42 and 2.08) in the first and the second seasons, respectively, were obtained from sowing on $10^{\text {th }}$ Nov. The increase in the number of branches/plant due to sowing during $25^{\text {th }}$ Oct. may be attributed to corresponding environmental conditions in order to maximum faba bean growth and development. These results are in harmony with those obtained by Sharaan et al. (2004) and Alazaki and Al-Shebani (2012)who reported that, number of branches / plant increased by increasing sowing dates.

Table 2: Effect of sowing dates,foliar withzinc and their interactions on number of branches /plant of two faba beanvarieties in $2016 / 17$ and $2017 / 18$ seasons.

\begin{tabular}{|c|c|c|c|c|c|c|c|c|c|}
\hline \multicolumn{2}{|c|}{ Seasons } & \multirow{2}{*}{\multicolumn{3}{|c|}{$\begin{array}{c}\text { 2016/17 } \\
\text { Foliar with zinc (ppm) }\end{array}$}} & \multirow[b]{3}{*}{ Mean } & \multicolumn{4}{|c|}{$2017 / 18$} \\
\hline \multirow[t]{2}{*}{ Varieties } & \multirow{2}{*}{$\begin{array}{c}\text { Sowing } \\
\text { dates }\end{array}$} & & & & & Foliar n & h zinc & pm) & \\
\hline & & Control & 30 & 60 & & Control & 30 & 60 & Mean \\
\hline \multirow{3}{*}{ Misr-1 } & $10^{\text {th }}$ Oct. & 2.51 & 3.79 & 4.12 & 3.48 & 2.12 & 3.58 & 3.89 & 3.19 \\
\hline & $25^{\text {th }}$ Oct. & 3.58 & 4.53 & 4.78 & 4.30 & 3.16 & 4.10 & 4.51 & 3.92 \\
\hline & $10^{\text {th }}$ Nov. & 1.98 & 2.65 & 2.86 & 2.50 & 1.64 & 2.30 & 2.52 & 2.15 \\
\hline \multicolumn{2}{|c|}{ Mean } & 2.69 & 3.66 & 3.92 & 3.42 & 2.31 & 3.32 & 3.64 & 3.09 \\
\hline \multirow{3}{*}{ Giza- 40} & $10^{\text {th }}$ Oct. & 2.96 & 3.82 & 3.98 & 3.59 & 2.55 & 3.46 & 3.81 & 3.27 \\
\hline & $25^{\text {th }}$ Oct. & 3.31 & 4.49 & 4.56 & 4.12 & 2.99 & 3.93 & 4.18 & 3.70 \\
\hline & $10^{\text {th }}$ Nov. & 1.82 & 2.63 & 2.56 & 2.34 & 1.50 & 2.22 & 2.33 & 2.01 \\
\hline \multicolumn{2}{|c|}{ Mean } & 2.70 & 3.65 & 3.70 & 3.35 & 2.34 & 3.20 & 3.44 & 2.99 \\
\hline Mean for & $10^{\text {th }}$ Oct. & 2.74 & 3.81 & 4.05 & 3.53 & 2.33 & 3.52 & 3.85 & 3.23 \\
\hline Sowing & $25^{\text {th }}$ Oct. & 3.45 & 4.51 & 4.67 & 4.21 & 3.08 & 4.01 & 4.34 & 3.81 \\
\hline dates & $10^{\text {th }}$ Nov. & 1.90 & 2.64 & 2.71 & 2.42 & 1.57 & 2.26 & 2.42 & 2.08 \\
\hline \multicolumn{2}{|c|}{ Mean } & 2.70 & 3.65 & 3.81 & & 2.33 & 3.26 & 3.54 & \\
\hline \multicolumn{2}{|c|}{ L.S.D. at 5\% for } & \multicolumn{4}{|c|}{$2016 / 17$} & \multicolumn{4}{|c|}{$2017 / 18$} \\
\hline \multicolumn{2}{|c|}{ Varieties (A) } & \multicolumn{4}{|c|}{ N.S } & \multicolumn{4}{|c|}{ N.S } \\
\hline \multicolumn{2}{|c|}{ Sowing dates (B) } & \multicolumn{4}{|c|}{0.13} & \multicolumn{4}{|c|}{0.83} \\
\hline \multicolumn{2}{|c|}{$\operatorname{Zinc}(\mathrm{C})$} & \multicolumn{4}{|c|}{0.11} & \multicolumn{4}{|c|}{0.11} \\
\hline \multicolumn{2}{|l|}{$\mathrm{AXB}$} & \multicolumn{4}{|c|}{ N.S } & \multicolumn{4}{|c|}{0.12} \\
\hline \multicolumn{2}{|l|}{$\mathrm{A} \mathrm{X} \mathrm{C}$} & \multicolumn{4}{|c|}{ N.S } & \multicolumn{4}{|c|}{ N.S } \\
\hline \multicolumn{2}{|l|}{ B X C } & \multicolumn{4}{|c|}{0.19} & \multicolumn{4}{|c|}{0.17} \\
\hline \multicolumn{2}{|c|}{$\mathrm{A} X \mathrm{~B} X \mathrm{C}$} & & & N.S & & & & N.S & \\
\hline
\end{tabular}


The foliar application of faba bean plants with zinc exerted a significant influence on number of branches/plant in the first and the second seasons. In general, number of branches/plant were increasing gradually with increasing zinc levels from 0.0 to $60 \mathrm{ppm}$ in both seasons. These results may be due the fact that zinc is important in the formation of the plant growth hormone auxins.

Auxins are produced by shoot tips, and control cell division, leaf and shoot growth and fruit development. These results are in agreement with those obtained by El-Gizawy and Mehasen (2009) and Saad (2015).

The presented results show that, the number of branches/plant were significantly affected by the interactions of varieties (A) $\mathrm{x}$ sowing dates (B) in the second season, where the highest value 3.92 was obtained from sowing faba bean Misr-1 variety in $25^{\text {th }}$ Oct., the interactions of sowing dates (B) and zinc (C) was significant in both seasons, where the highest values of 4.67 and 4.34 were obtained from sowing faba bean at $25^{\text {th }}$ Oct. and $60 \mathrm{ppm}$ zinc in the first and second seasons, respectively. The other interactions did not show significant effect on this trait.

\section{2- Number of pods/plant.}

Results in Table (3) showed that, the two studied varieties did not significantly differed in number of pods/plant in both seasons. These results are agreement with those obtained by Bakheit et al. (2001) and Hassan (2016).
Results indicated that, sowing dates had a significant effect on this trait in both seasons. As seen from obtained results, sowing faba bean plants on $25^{\text {th }}$ Oct. achieved maximum increase in number of pods/plant (15.75 and 15.65) in the first and the second seasons, respectively. On contrary of that, the lowest means of number of pods/plant(13.63 and 13.50) was product due to sowing faba bean plants on $10^{\text {th }}$ Nov.in the first and the second seasons, respectively. The desirable effect of sowing faba bean on $25^{\text {th }}$ Oct. on number of pods/plant might be ascribed to the seasonal environmental condition during this period such as temperature, day length and light intensity which allow to rapid germination, establishment, vegetative growth, development and ripening consequently increasing dry matter accumulation. These results are in agreement with this obtained by Alazaki and Al-Shebani (2012).

The foliar with zinc at the level of 30 to 60 ppm had a significant increase in the number of pods/plant more than the untreated plants, in the both seasons Table (3). Zinc plays an essential role in plant physiology, where it actives some of enzymes such as dehydrogenises, pretenses, peptidases and phosphohydrolases. These results might be due to the fact that, zinc is also needed by leaf cells to form the green leaf pigment chlorophyll. The results of the effect zinc on number of pods obtained in the study are in agreement with those obtained by El-Gizawy and Mehasen (2009).

Table 3: Effect of sowing dates, foliar with zinc and their interactions on number of pods /plant of two faba bean varieties in $2016 / 17$ and $2017 / 18$ seasons.

\begin{tabular}{|c|c|c|c|c|c|c|c|c|c|}
\hline \multicolumn{2}{|c|}{ Seasons } & \multicolumn{4}{|c|}{ 2016/17 } & \multicolumn{4}{|c|}{$2017 / 18$} \\
\hline \multirow[b]{2}{*}{ Varieties } & \multirow{2}{*}{$\begin{array}{c}\text { Sowing } \\
\text { dates }\end{array}$} & \multicolumn{3}{|c|}{ Foliar with zinc (ppm) } & \multirow[b]{2}{*}{ Mean } & \multicolumn{3}{|c|}{ Foliar with zinc (ppm) } & \multirow[b]{2}{*}{ Mean } \\
\hline & & Control & 30 & 60 & & Control & 30 & 60 & \\
\hline \multirow{3}{*}{ Misr-1 } & $10^{\text {th }}$ Oct. & 13.48 & 14.98 & 15.05 & 14.51 & 13.38 & 14.89 & 15.03 & 14.43 \\
\hline & $25^{\text {th }}$ Oct. & 15.43 & 15.89 & 15.92 & 15.75 & 15.12 & 15.79 & 15.90 & 15.60 \\
\hline & $10^{\text {th }}$ Nov. & 12.55 & 14.11 & 14.13 & 13.60 & 12.28 & 14.04 & 14.13 & 13.48 \\
\hline \multicolumn{2}{|c|}{ Mean } & 13.82 & 14.99 & 15.03 & 14.62 & 13.59 & 14.90 & 15.02 & 14.50 \\
\hline \multirow{3}{*}{ Giza- 40} & $10^{\text {th }}$ Oct. & 13.55 & 15.35 & 15.06 & 14.65 & 13.52 & 14.92 & 15.06 & 14.50 \\
\hline & $25^{\text {th }}$ Oct. & 15.60 & 15.82 & 15.83 & 15.75 & 15.74 & 15.57 & 15.82 & 15.71 \\
\hline & $10^{\text {th }}$ Nov. & 12.71 & 14.11 & 14.17 & 13.67 & 12.42 & 13.96 & 14.17 & 13.52 \\
\hline \multicolumn{2}{|c|}{ Mean } & 13.95 & 15.09 & 15.02 & 14.69 & 13.89 & 14.81 & 15.02 & 14.57 \\
\hline Mean for & $10^{\text {th }}$ Oct. & 13.51 & 15.16 & 15.05 & 14.58 & 13.45 & 14.90 & 15.05 & 14.46 \\
\hline Sowing & $25^{\text {th }}$ Oct. & 15.51 & 15.85 & 15.87 & 15.75 & 15.43 & 15.68 & 15.86 & 15.65 \\
\hline dates & $10^{\text {th }}$ Nov. & 12.63 & 14.11 & 14.15 & 13.63 & 12.35 & 14.00 & 14.15 & 13.50 \\
\hline \multicolumn{2}{|c|}{ Mean } & 13.89 & 15.04 & 15.03 & & 13.74 & 14.86 & 15.02 & \\
\hline \multicolumn{2}{|c|}{ L.S.D. at 5\% for } & \multicolumn{4}{|c|}{ 2016/17 } & \multicolumn{4}{|c|}{$2017 / 18$} \\
\hline \multicolumn{2}{|c|}{ Varieties (A) } & \multicolumn{4}{|c|}{ N.S } & \multicolumn{4}{|c|}{ N.S } \\
\hline \multicolumn{2}{|c|}{ Sowing dates (B) } & \multicolumn{4}{|c|}{0.07} & \multicolumn{4}{|c|}{0.06} \\
\hline \multicolumn{2}{|c|}{ Zinc (C) } & \multicolumn{4}{|c|}{0.13} & \multicolumn{4}{|c|}{0.12} \\
\hline \multicolumn{2}{|l|}{ A X B } & \multicolumn{4}{|c|}{ N.S } & \multicolumn{4}{|c|}{0.17} \\
\hline \multicolumn{2}{|l|}{$\mathrm{AXC}$} & \multicolumn{4}{|c|}{ N.S } & \multicolumn{4}{|c|}{ N.S } \\
\hline \multicolumn{2}{|l|}{$\mathrm{B} X \mathrm{C}$} & & & & & & & & \\
\hline A X B X & & & & & & & & $S$ & \\
\hline
\end{tabular}


Results in Table (3) indicated that, the interaction between varieties $\mathrm{x}$ sowing dates had significant effect on this trait the second season only where the highest values of 15.71 and 15.60 were obtained from sowing faba bean Giza-40 or Misr-1 varietiesin $25^{\text {th }}$ Oct., where there is no significant difference between both interaction Also, number of pods/plant was significantly affected by the interaction between sowing dates and zinc in the two seasons, where the interaction between $25^{\text {th }}$ Oct. date of sowing and each of 30 or $60 \mathrm{ppm}$ zinc gave the highest values in both seasons with no significant difference between them. The three way interaction was not significant in both seasons.

\section{3- Seed yield /plant (g):-}

Data in Table (4) indicted that, seed yield/plant was significantly affected by varieties only in 2017/18 season, where Misr-1 variety had higher seed yield /plant than Giza-40. The differences between faba bean varieties in seed yield/plant may be due to the differences in partitioning and migration of photosynthetic between faba bean varieties and in the content of endogenous hormones. These results are in harmony with those found by Sharaan et al. (2004) and El-Bannaet al. (2009).
The data presents in Table (4) showed that seed yield/plant was significantly by sowing dates in the two seasons. By dwelling obtained data, the highest values of seed yield/plant 40.69 and $40.06 \mathrm{~g}$ in the first and the second seasons, respectively, could be obtained from sowing faba bean plants on $25^{\text {th }}$ Oct.. On the contrary of that, the lowest means in the these terms 33.64 and $32.85 \mathrm{~g}$ in the first and the second seasons, respectively, were obtained from sowing on $10^{\text {th }}$ Nov. The increase inseed yield/plant due to sowing during $25^{\text {th }}$ Oct. might be ascribed to more suitable weather condition i.e. temperature and light intensity which allow to better establishment and vegetative growth, hence formation good canopy capable to increase photosynthesis process. It is worthy to mention that there results are in good agreement with those obtained by Bakheitet al. (2001), El-Gizawy and Mehasen (2009) and Abido and Seadh (2014).

Results in Table (4) showed that, foliar application with zinc up to $60 \mathrm{ppm}$ significantly increased seed yield/plant in both seasons, where the highest values 40.28 and $40.19 \mathrm{~g}$ were obtained when zinc of $60 \mathrm{ppm}$ in both seasons, respectively. Zinc is one of the most important essential micronutrients required for optimum crop growth. It plays an important role in many biochemical reactions within plants.

Table 4: Effect of sowing dates, foliar with zinc and their interactions on seed yield /plant (g)of two faba bean varieties in $2016 / 17$ and $2017 / 18$ seasons.

\begin{tabular}{|c|c|c|c|c|c|c|c|c|c|}
\hline \multicolumn{2}{|c|}{ Seasons } & \multirow{2}{*}{\multicolumn{3}{|c|}{$\begin{array}{c}2016 / 17 \\
\text { Foliar with zinc (ppm) }\end{array}$}} & \multirow[b]{3}{*}{ Mean } & \multicolumn{4}{|c|}{$2017 / 18$} \\
\hline \multirow[t]{2}{*}{ Varieties } & \multirow{2}{*}{$\begin{array}{c}\text { Sowing } \\
\text { dates }\end{array}$} & & & & & \multicolumn{3}{|c|}{ Foliar with zinc (ppm) } & \multirow[b]{2}{*}{ Mean } \\
\hline & & Control & 30 & 60 & & Control & 30 & 60 & \\
\hline \multirow{3}{*}{ Misr-1 } & $10^{\text {th }}$ Oct. & 33.41 & 38.9 & 41.26 & 37.73 & 32.48 & 37.04 & 41.18 & 36.90 \\
\hline & $25^{\text {th }}$ Oct. & 39.71 & 41.15 & 42.38 & 41.08 & 38.64 & 40.34 & 42.17 & 40.38 \\
\hline & $10^{\text {th }}$ Nov. & 29.71 & 34.15 & 38.18 & 34.01 & 28.57 & 33.00 & 38.12 & 33.23 \\
\hline \multicolumn{2}{|c|}{ Mean } & 34.28 & 37.93 & 40.60 & 37.61 & 33.23 & 36.79 & 40.49 & 36.84 \\
\hline \multirow{3}{*}{ Giza- 40} & $10^{\text {th }}$ Oct. & 32.56 & 39.04 & 40.77 & 37.45 & 31.66 & 38.19 & 40.70 & 36.85 \\
\hline & $25^{\text {th }}$ Oct. & 37.10 & 41.81 & 41.98 & 40.30 & 36.70 & 40.65 & 41.91 & 39.75 \\
\hline & $10^{\text {th }}$ Nov. & 29.16 & 33.52 & 37.11 & 33.26 & 27.92 & 32.49 & 37.05 & 32.48 \\
\hline \multicolumn{2}{|c|}{ Mean } & 32.94 & 38.12 & 39.95 & 37.01 & 32.09 & 37.11 & 39.88 & 36.36 \\
\hline Mean for & $10^{\text {th }}$ Oct. & 32.98 & 38.76 & 41.02 & 37.59 & 32.07 & 37.61 & 40.94 & 36.87 \\
\hline Sowing & $25^{\text {th }}$ Oct. & 38.40 & 41.48 & 42.18 & 40.69 & 37.67 & 40.49 & 42.04 & 40.06 \\
\hline dates & $10^{\text {th }}$ Nov. & 29.44 & 33.83 & 37.65 & 33.64 & 28.24 & 32.74 & 37.58 & 32.85 \\
\hline \multicolumn{2}{|c|}{ Mean } & 33.61 & 38.02 & 40.28 & & 32.66 & 36.95 & 40.19 & \\
\hline \multicolumn{2}{|c|}{ L.S.D. at $5 \%$ for } & \multicolumn{3}{|c|}{$2016 / 17$} & & \multicolumn{4}{|c|}{$2017 / 18$} \\
\hline \multicolumn{2}{|c|}{ Varieties (A) } & \multicolumn{3}{|c|}{ N.S } & & \multicolumn{4}{|c|}{ Sig. } \\
\hline \multicolumn{2}{|c|}{ Sowing dates (B) } & \multicolumn{3}{|c|}{0.34} & & \multicolumn{4}{|c|}{0.26} \\
\hline \multicolumn{2}{|l|}{ Zinc (C) } & \multicolumn{3}{|c|}{0.28} & & \multicolumn{4}{|c|}{0.25} \\
\hline \multicolumn{2}{|l|}{ A X B } & \multicolumn{3}{|c|}{ N.S } & & \multicolumn{4}{|c|}{0.37} \\
\hline \multicolumn{2}{|l|}{$\mathrm{AX} \mathrm{C}$} & \multicolumn{3}{|c|}{0.40} & & \multicolumn{4}{|c|}{0.36} \\
\hline \multicolumn{2}{|l|}{$\mathrm{B} X \mathrm{C}$} & \multicolumn{3}{|c|}{0.49} & & & & & \\
\hline A X B X & & & 0.69 & & & & & & \\
\hline
\end{tabular}


Zinc is important in the formation of the plant growth hormone auxins. Auxins are produced by shoot tips, and control cell division, leaf and shoot growth and fruit development Also, the increase in seed yield/plant might be associated with high number of pods and branches/plant and seed number /plant. The results are in the same line with those obtained by El-Gizawy and Mehasen (2009) and Saad (2015).

The presented results indicated that, seed yield/plant was significantly affected by the interaction; varieties $\mathrm{x}$ sowing dates in the second season only, where the highest seed yield/plant of $40.38 \mathrm{~g}$ was obtained from sowing faba bean Misr-1 variety in $25^{\text {th }}$ Oct. Also, was significantly affected by the interaction between varieties and zinc in the two seasons, where the highest values of 40.60 and $40.49 \mathrm{~g}$ were obtained from Misr-1 variety when received $60 \mathrm{ppm}$ zinc in the first and the second seasons, respectively. Seed yield/plant was significantly affected by the interaction between sowing dates and zinc in both seasons, where the highest values (42.18 and 42.04) were obtained when sowing faba bean plants in $25^{\text {th }}$ Oct. and received $60 \mathrm{ppm}$ zinc in the first and the second seasons, respectively. The second order interaction exerted significant effect on seed yield/plant in 2016/17 and 2017/18 seasons, where the highest values of 42.37 and $42.17 \mathrm{~g}$ were obtained from sowing faba bean Misr-1 variety in $25^{\text {th }}$ Oct. and received $60 \mathrm{ppm}$ zinc in both seasons, respectively.

\section{4- 100-seed weight (g):-}

Data in Table (5) showed that, 100-seed weight was significantly different between varieties in 2016/17 and 2017/18 seasons. Misr-1 variety surpassed Giza-40 variety. The differences between faba bean varieties in 100-seed weight may be due to the differences in partitioning and migration of photosynthetic products between the two faba bean varieties and the endogenous hormones content. Results agreed with those obtained by Bakheit et al. (2001),Ragab et al. (2010) and Hassan (2016).

Sowing dates offaba bean plants had significant effect on 100-seed weight in both seasons. Generally, the optimum sowing date was on $25^{\text {th }}$ Oct. so that produced the highest values of 100 -seed weight, which results were 70.86 and $70.73 \mathrm{~g}$ in the first and the second seasons, respectively, On the contrary of that, the lowest means of 100-seed weight, which results were 66.12 and $65.70 \mathrm{~g}$ in the first and the second seasons, respectively, were achieved when delaying sowing up to $10^{\text {th }}$ Nov. Might be ascribed to more suitable weather condition i.e. temperature and light intensity which allow to better establishment and vegetative growth, hence formation good canopy to increasing photosynthesis process, which might interpret the increase seed yield/plant and this might account much for a good seed filling and subsequently higher seed index.

Table 5: Effect of sowing dates, foliar with zinc and their interactions on 100-seed weight (g) of two faba bean varieties in $2016 / 17$ and $2017 / 18$ seasons.

\begin{tabular}{|c|c|c|c|c|c|c|c|c|c|}
\hline \multicolumn{2}{|c|}{ Seasons } & \multicolumn{4}{|c|}{ 2016/17 } & \multicolumn{4}{|c|}{$2017 / 18$} \\
\hline \multirow[b]{2}{*}{ Varieties } & \multirow{2}{*}{$\begin{array}{c}\text { Sowing } \\
\text { dates }\end{array}$} & \multicolumn{3}{|c|}{ Foliar with zinc (ppm) } & \multirow[b]{2}{*}{ Mean } & \multicolumn{3}{|c|}{ Foliar with zinc (ppm) } & \multirow[b]{2}{*}{ Mean } \\
\hline & & Control & 30 & 60 & & Control & 30 & 60 & \\
\hline \multirow{3}{*}{ Misr-1 } & $10^{\text {th }}$ Oct. & 68.02 & 71.26 & 73.49 & 70.92 & 66.89 & 71.05 & 73.12 & 70.35 \\
\hline & $25^{\text {th }}$ Oct. & 69.39 & 71.75 & 73.18 & 71.44 & 69.19 & 71.58 & 73.38 & 71.37 \\
\hline & $10^{\text {th }}$ Nov. & 62.52 & 67.94 & 69.17 & 66.54 & 61.43 & 67.10 & 69.81 & 66.11 \\
\hline \multicolumn{2}{|c|}{ Mean } & 66.64 & 70.32 & 71.95 & 69.64 & 65.82 & 69.91 & 72.10 & 69.28 \\
\hline \multirow{3}{*}{ Giza- 40} & $10^{\text {th }}$ Oct. & 66.68 & 68.05 & 69.37 & 68.03 & 66.30 & 68.90 & 69.23 & 68.14 \\
\hline & $25^{\text {th }}$ Oct. & 69.22 & 69.71 & 71.92 & 70.28 & 68.94 & 69.49 & 71.83 & 70.09 \\
\hline & $10^{\text {th }}$ Nov. & 62.37 & 66.02 & 68.68 & 65.69 & 62.09 & 65.32 & 68.46 & 65.29 \\
\hline \multicolumn{2}{|c|}{ Mean } & 66.09 & 67.93 & 69.99 & 68.00 & 65.77 & 67.90 & 69.84 & 67.84 \\
\hline Mean for & $10^{\text {th }}$ Oct. & 67.35 & 69.66 & 71.43 & 69.48 & 66.59 & 69.97 & 71.17 & 69.24 \\
\hline Sowing & $25^{\text {th }}$ Oct. & 69.31 & 70.73 & 72.55 & 70.86 & 69.04 & 70.54 & 72.60 & 70.73 \\
\hline dates & $10^{\text {th }}$ Nov. & 62.44 & 66.98 & 68.93 & 66.12 & 61.76 & 66.21 & 69.13 & 65.70 \\
\hline \multicolumn{2}{|c|}{ Mean } & 66.37 & 69.12 & 70.97 & & 65.80 & 68.90 & 70.97 & \\
\hline \multicolumn{2}{|c|}{ L.S.D. at 5\% for } & & \multicolumn{3}{|c|}{$2016 / 17$} & \multicolumn{4}{|c|}{$2017 / 18$} \\
\hline \multicolumn{2}{|c|}{ Varieties (A) } & & \multicolumn{3}{|c|}{ Sig. } & \multicolumn{4}{|c|}{ Sig. } \\
\hline \multicolumn{2}{|c|}{ Sowing dates (B) } & & \multicolumn{3}{|c|}{0.31} & \multicolumn{4}{|c|}{0.18} \\
\hline \multicolumn{2}{|l|}{ Zinc (C) } & & \multicolumn{3}{|c|}{0.38} & \multicolumn{4}{|c|}{0.21} \\
\hline \multicolumn{2}{|l|}{ A X B } & & \multicolumn{3}{|c|}{0.44} & \multicolumn{4}{|c|}{0.27} \\
\hline \multicolumn{2}{|l|}{$\mathrm{AX} \mathrm{C}$} & & \multicolumn{3}{|c|}{0.54} & \multicolumn{4}{|c|}{0.30} \\
\hline \multicolumn{2}{|l|}{$\mathrm{B} \mathrm{X} \mathrm{C}$} & & & 0.66 & & & & 0.37 & \\
\hline A X B X & $\mathrm{C}$ & & & N.S & & & & 0.52 & \\
\hline
\end{tabular}


These results are in the same trend with those found by Bakheit et al. (2001), El-Gizawy and Mehasen (2009) and Abido and Seadh (2014) who reported that 100 -seed weight was increased by delaying sowing dates.

The application of zinc to faba bean plants exerted a significant influence on 100-seed weight in both seasons. In general, the highest 100-seed weight was recorded when applied zinc to faba bean plants at the level of 60 ppmin 2016/17 and 2017/18 seasons. These results are in the same line with those found by Saad (2015). This may bedue to that zinc increased the vegetative growth of faba bean, inaddition to, the role of zinc in enhancing photosynthesis process.

The presented results illustrate that 100 -seed weight was significantly affected by the interaction between varieties and sowing dates in both seasons, where the highest values of 71.44 and $71.37 \mathrm{~g}$ were obtained for sowingfaba bean Misr-1 variety in $25^{\text {th }}$ Oct. in the first and the second seasons, respectively. Also, 100 -seed weight was significantly affected by the interaction between varieties and zinc in the two seasons, where the highest values of 71.95 and 72.10 $\mathrm{g}$ were obtained for Misr-1 variety when received 60 ppm zinc in the first and the second seasons, respectively. Moreover, 100 -seed weight was significantly affected by the interaction between sowing dates and zinc,where the highest values of 72.55 and $72.60 \mathrm{~g}$ were obtained in plants sown in $25^{\text {th }}$ Oct. and received $60 \mathrm{ppm}$ zinc in both seasons, respectively. The second order interaction was exerted a significant effect on 100 -seed weight in the second season only, where the highest value (73.38 g) was obtained from sowingfaba bean Misr1 variety in $25^{\text {th }}$ Oct. and foliar application with 60 ppm zinc .

5- Seed yield (ard. /fad.):-

The presented results in Table (6) indicated that, the difference between the two faba bean varieties were significant for seed yield /fad. in 2016/17 and 2018/18 seasons. Furthermore, results showed clearly that ,Misr -1 variety surpassed Giza -40 variety during the two seasons. The differences between faba bean varieties in the productivity potential efficiency may be due to the genetical constituents and its interaction with environmental conditions which reflected on partitioning and migration of photosynthetic between faba bean varieties, consequently an increase in number of pods/plant, seeds yield /plants and seed index, particularly in both seasons. These results are in harmony with those found by El-Bannaet al. (2009) and Hassan (2016).

Table 6: Effect of sowing dates, foliar with zinc and their interactions on seed yield (ard./fad.)of two faba bean varieties in $2016 / 17$ and $2017 / 18$ seasons.

\begin{tabular}{|c|c|c|c|c|c|c|c|c|c|}
\hline \multicolumn{2}{|c|}{ Seasons } & \multicolumn{4}{|c|}{$2016 / 17$} & \multicolumn{4}{|c|}{$2017 / 18$} \\
\hline \multirow[b]{2}{*}{ Varieties } & \multirow{2}{*}{$\begin{array}{c}\text { Sowing } \\
\text { dates }\end{array}$} & \multicolumn{3}{|c|}{ Foliar with zinc (ppm) } & \multirow[b]{2}{*}{ Mean } & \multicolumn{3}{|c|}{ Foliar with zinc (ppm) } & \multirow[b]{2}{*}{ Mean } \\
\hline & & Control & 30 & 60 & & Control & 30 & 60 & \\
\hline \multirow{3}{*}{ Misr-1 } & $10^{\text {th }}$ Oct. & 9.88 & 10.89 & 11.23 & 10.66 & 9.70 & 10.67 & 10.86 & 10.41 \\
\hline & $25^{\text {th }}$ Oct. & 10.97 & 11.86 & 11.88 & 11.57 & 10.78 & 11.60 & 11.82 & 11.40 \\
\hline & $10^{\text {th }}$ Nov. & 8.94 & 9.29 & 9.67 & 9.30 & 8.87 & 9.16 & 9.45 & 9.16 \\
\hline \multicolumn{2}{|c|}{ Mean } & 9.93 & 10.68 & 10.93 & 10.51 & 9.78 & 10.48 & 10.71 & 10.32 \\
\hline \multirow{3}{*}{ Giza- 40} & $10^{\text {th }}$ Oct. & 9.29 & 10.47 & 10.95 & 10.24 & 9.17 & 10.12 & 10.70 & 10.00 \\
\hline & $25^{\text {th }}$ Oct. & 10.47 & 11.17 & 11.25 & 10.96 & 10.31 & 10.92 & 11.13 & 10.79 \\
\hline & $10^{\text {th }}$ Nov. & 8.52 & 9.21 & 9.51 & 9.08 & 8.30 & 9.02 & 9.32 & 8.88 \\
\hline \multicolumn{2}{|c|}{ Mean } & 9.42 & 10.28 & 10.57 & 10.09 & 9.26 & 10.02 & 10.38 & 9.89 \\
\hline Mean for & $10^{\text {th }}$ Oct. & 9.59 & 10.68 & 11.09 & 10.45 & 9.43 & 10.39 & 10.78 & 10.20 \\
\hline Sowing & $25^{\text {th }}$ Oct. & 10.72 & 11.52 & 11.56 & 11.26 & 10.54 & 11.26 & 11.47 & 11.09 \\
\hline dates & $10^{\text {th }}$ Nov. & 8.73 & 9.25 & 9.59 & 9.19 & 8.58 & 9.09 & 9.38 & 9.02 \\
\hline \multicolumn{2}{|c|}{ Mean } & 9.68 & 10.48 & 10.75 & & 9.52 & 10.25 & 10.55 & \\
\hline \multicolumn{2}{|c|}{ L.S.D. at $5 \%$ for } & \multicolumn{3}{|c|}{ 2016/17 } & & \multicolumn{4}{|c|}{$2017 / 18$} \\
\hline \multicolumn{2}{|c|}{ Varieties (A) } & \multicolumn{3}{|c|}{ Sig. } & & \multicolumn{4}{|c|}{ Sig. } \\
\hline \multicolumn{2}{|c|}{ Sowing dates (B) } & \multicolumn{3}{|c|}{0.15} & & \multicolumn{4}{|c|}{0.13} \\
\hline \multicolumn{2}{|c|}{ Zinc (C) } & \multicolumn{4}{|c|}{0.10} & \multicolumn{4}{|c|}{0.12} \\
\hline \multicolumn{2}{|l|}{$\mathrm{AXB}$} & \multicolumn{4}{|c|}{0.21} & \multicolumn{4}{|c|}{ N.S } \\
\hline \multicolumn{2}{|l|}{$\mathrm{AX} \mathrm{C}$} & \multicolumn{4}{|c|}{ N.S } & \multicolumn{4}{|c|}{ N.S } \\
\hline \multicolumn{2}{|l|}{$\mathrm{BX}$ X } & & & & & & & & \\
\hline A X B X & & & & & & & & & \\
\hline
\end{tabular}


It could be concluded that, the sowing dates had significant effect on this trait in both seasons, by dwelling obtained data, the highest values of seed yield /fad. 11.26 and 11.09 ard. /fad. in the first and the second seasons, respectively, could be obtained from sowing faba bean plants on $25^{\text {th }}$ Oct.. On the contrary of that, the lowest means in seed yield /fad. 9.19 and $9.02 \mathrm{ard}$. /fad. in the first and the second seasons, respectively, were obtained from sowing on $10^{\text {th }}$ Nov.

The desirable effect of sowing faba bean on $25^{\text {th }}$ Oct. on seed yield /fad. might be ascribed to the seasonal environmental condition during this period such as temperature, day length and light intensity which allow to rapid germination, establishment, vegetative growth, development and ripening consequently increasing dry matter accumulation, yield components as well as seed yield per unit area. It is worthy to mention that, these results are in good agreement with those obtained by Bakheit et al. (2001) and El-Gizawy and Mehasen (2009).

It could be concluded that applied zinc had significant effect on seed yield ard./fad., in both seasons, where the highest seed yield /fad. (10.75 and 10.55 ard./fad.) were obtained when zinc was applied at a level of $60 \mathrm{ppm}$ in both seasons, respectively. Which may be due the increase in seed yield/fad.might be associated with high number of pods and number of branches/plant, 100 -seed weight and seed yield/plant. The result of zinc for seed yield ard./fad. obtained in the study are in agreement with those obtained by ElGizawy and Mehasen (2009).

Data recorded in Table (6) showed that, the interaction between varieties $\mathrm{x}$ sowing dates was significant in the first season only, where the highest value of $11.57 \mathrm{ard}$./fad. was recorded for sowingfaba bean Misr-1 variety in $25^{\text {th }}$ Oct. Also, seed yield/fad.was significantly affected by the interaction between sowing dates and zinc in both seasons, where the highest values 11.56 and 11.47 ard./fad. were obtained which $25^{\text {th }}$ Oct. date of sowing interacted with the application of $60 \mathrm{ppm}$ zinc in both seasons, respectively. The varieties $\mathrm{x}$ zinc interaction and the second order interaction were insignificantly affected the trait in view both seasons.

\section{6- Straw yield (ton/fad.).}

Results in Table (7) illustrated that, the differences between the two faba bean varieties were significant for straw yield ton /fad. in 2016/17 and 2017/18 seasons. Misr-1 variety had higher straw yield /fad. than Giza-40 variety in both seasons. The differences between faba bean varieties in straw yield could be due to the differences in partitioning and migration of photosynthetic, plant height and number of branches/plant. These results agreed with those obtained by Ahmed and El-Abagy (2007) and Hassan (2016).

Table 7: Effect of sowing dates, foliar with zinc and their interactions on straw yield (ton/fad.) of two faba bean varieties in $2016 / 17$ and $2017 / 18$ seasons.

\begin{tabular}{|c|c|c|c|c|c|c|c|c|c|}
\hline \multicolumn{2}{|c|}{ Seasons } & \multicolumn{3}{|c|}{ 2016/17 } & \multicolumn{5}{|c|}{$2017 / 18$} \\
\hline \multirow[b]{2}{*}{ Varieties } & \multirow{2}{*}{$\begin{array}{c}\text { Sowing } \\
\text { dates }\end{array}$} & \multicolumn{3}{|c|}{ Foliar with zinc (ppm) } & \multirow[b]{2}{*}{ Mean } & \multicolumn{3}{|c|}{ Foliar with zinc (ppm) } & \multirow[b]{2}{*}{ Mean } \\
\hline & & Control & 30 & 60 & & Control & 30 & 60 & \\
\hline \multirow{3}{*}{ Misr-1 } & $10^{\text {th }}$ Oct. & 2.29 & 2.45 & 2.74 & 2.49 & 2.22 & 2.34 & 2.62 & 2.39 \\
\hline & $25^{\text {th }}$ Oct. & 2.41 & 2.51 & 2.78 & 2.57 & 2.35 & 2.43 & 2.74 & 2.50 \\
\hline & $10^{\text {th }}$ Nov. & 2.16 & 2.30 & 2.58 & 2.35 & 2.11 & 2.21 & 2.43 & 2.25 \\
\hline \multicolumn{2}{|c|}{ Mean } & 2.28 & 2.42 & 2.70 & 2.47 & 2.22 & 2.32 & 2.60 & 2.38 \\
\hline \multirow{3}{*}{ Giza- 40} & $10^{\text {th }}$ Oct. & 2.20 & 2.30 & 2.58 & 2.36 & 2.13 & 2.20 & 2.46 & 2.26 \\
\hline & $25^{\text {th }}$ Oct. & 2.32 & 2.40 & 2.64 & 2.45 & 2.27 & 2.36 & 2.58 & 2.40 \\
\hline & $10^{\text {th }}$ Nov. & 2.07 & 2.24 & 2.51 & 2.27 & 2.02 & 2.17 & 2.34 & 2.17 \\
\hline \multicolumn{2}{|c|}{ Mean } & 2.20 & 2.31 & 2.58 & 2.36 & 2.14 & 2.24 & 2.46 & 2.28 \\
\hline Mean for & $10^{\text {th }}$ Oct. & 2.24 & 2.37 & 2.66 & 2.42 & 2.17 & 2.27 & 2.54 & 2.33 \\
\hline Sowing & $25^{\text {th }}$ Oct. & 2.36 & 2.45 & 2.71 & 2.51 & 2.31 & 2.39 & 2.66 & 2.45 \\
\hline dates & $10^{\text {th }}$ Nov. & 2.11 & 2.27 & 2.55 & 2.31 & 2.06 & 2.19 & 2.38 & 2.21 \\
\hline \multicolumn{2}{|c|}{ Mean } & 2.24 & 2.36 & 2.64 & & 2.18 & 2.28 & 2.53 & \\
\hline \multicolumn{2}{|c|}{ L.S.D. at 5\% for } & \multicolumn{3}{|c|}{$2016 / 17$} & \multicolumn{5}{|c|}{$2017 / 18$} \\
\hline \multicolumn{2}{|c|}{ Varieties (A) } & \multicolumn{3}{|c|}{ Sig. } & \multicolumn{5}{|c|}{ Sig. } \\
\hline \multicolumn{2}{|c|}{ Sowing dates (B) } & \multicolumn{3}{|c|}{0.05} & \multicolumn{5}{|c|}{0.04} \\
\hline \multicolumn{2}{|c|}{ Zinc (C) } & \multicolumn{3}{|c|}{0.06} & \multicolumn{5}{|c|}{0.05} \\
\hline \multicolumn{2}{|l|}{ A X B } & \multicolumn{3}{|c|}{ N.S } & \multicolumn{5}{|c|}{ N.S } \\
\hline \multicolumn{2}{|l|}{$\mathrm{AX} \mathrm{C}$} & \multicolumn{3}{|c|}{ N.S } & \multicolumn{5}{|c|}{ N.S } \\
\hline \multicolumn{2}{|l|}{$\mathrm{B} \mathrm{X} \mathrm{C}$} & & N.S & & & & N.S & & \\
\hline A X B X & & & N.S & & & & N.S & & \\
\hline
\end{tabular}


The data in Table (7) illustrated that, sowing dates had a significant effect on this trait in two seasons, where the highest means straw yield ton /fad. (2.51 and 2.45 ton/fad.) were obtained on account of sowing faba bean plants on $25^{\text {th }}$ Oct. in the first and the second seasons, respectively. However, the lowest one of this trait (2.31 and $2.21 \mathrm{ton} / \mathrm{fad}$.) in the first and the second seasons, respectively, were obtained from sowing on $10^{\text {th }}$ Nov. The stimulatory effect on straw yield /fad. observed in this trait due to sowing on $25^{\text {th }}$ Oct. may be attributed to the suitable weather condition during vegetative growth, which contributed to good leaves growth and formation ample canopy able to make best photosynthesis. It is worthy to mention that, these results are in good agreement with those obtained by Bakheit et al. (2001), ElGizawy and Mehasen (2009).

Data in Table (7) indicated that, application of zinc to faba bean plants exerted a significant effect on straw yield in 2016/17 and 2017/18 seasons. In general, the highest straw yield/fad.was recorded when applied zinc at level of $60 \mathrm{ppm}$ compared to the control in the two seasons. These results may be due to the ability of zinc in the formation of the plant growth hormone auxins. Auxins are produced by shoot tips, and control cell division, leaf and shoot growth and fruit development. These results are in agreement with those obtained by El-Gizawy and Mehasen (2009) and Saad (2015).

The Results revealed that,straw yield ton/fad.was not significantly affected by the interactions among experiment factors.

\section{B- Chemical analysis:-}

\section{Protein percentage:-}

Illustrated results in Table (8) clearly indicated that, the two varieties were significantly different for seed protein percentage in 2016/17 and 2017/18 seasons. Misr-1 variety surpassed Giza-40 in protein percentage in both seasons. These results are in the same line with those found by Ahmed and El-Abagy (2007), El-Bannaet al. (2009) and Hassan (2016).

The results indicated that, sowing dates significantly affected protein content in faba bean seeds in both seasons. As seen from obtained results, sowing faba bean plants on $25^{\text {th }}$ Oct. achieved maximum increase in protein content $(29.27$ and $28.60 \%)$ in the first and the second seasons, respectively. On contrary of that, the lowest means of number of pods/plant $(2 r, 48$ and $21.9 \vee \%)$ was product due to sowing faba bean plants on $10^{\text {th }}$ Nov.in the first and the second seasons, respectively.

Table 8: Effect of sowing dates, foliar with zinc and their interactions on protein percentage of two faba bean varieties in $2016 / 17$ and $2017 / 18$ seasons.

\begin{tabular}{|c|c|c|c|c|c|c|c|c|c|}
\hline \multicolumn{2}{|c|}{ Seasons } & \multirow{2}{*}{\multicolumn{3}{|c|}{$\begin{array}{r}2016 / 17 \\
\text { Foliar with zinc (ppm) }\end{array}$}} & \multirow[b]{3}{*}{ Mean } & \multicolumn{4}{|c|}{$2017 / 18$} \\
\hline \multirow[t]{2}{*}{ Varieties } & \multirow{2}{*}{$\begin{array}{c}\text { Sowing } \\
\text { dates }\end{array}$} & & & & & \multicolumn{3}{|c|}{ Foliar with zinc (ppm) } & \multirow[b]{2}{*}{ Mean } \\
\hline & & Control & 30 & 60 & & Control & 30 & 60 & \\
\hline \multirow{3}{*}{ Misr-1 } & $10^{\text {th }}$ Oct. & 25.30 & 28.47 & 29.03 & 27.60 & 25.03 & 26.03 & 26.66 & 25.91 \\
\hline & $25^{\text {th }}$ Oct. & 27.26 & 30.60 & 30.77 & 29.54 & 27.43 & 29.40 & 29.96 & 28.93 \\
\hline & $10^{\text {th }}$ Nov. & 21.43 & 24.26 & 26.63 & 24.11 & 20.20 & 22.03 & 24.03 & 22.08 \\
\hline \multicolumn{2}{|c|}{ Mean } & 24.66 & 27.78 & 28.81 & 27.08 & 24.22 & 25.82 & 26.88 & 25.64 \\
\hline \multirow{3}{*}{ Giza- 40} & $10^{\text {th }}$ Oct. & 25.06 & 26.90 & 27.53 & 26.50 & 23.96 & 24.83 & 25.03 & 24.61 \\
\hline & $25^{\text {th }}$ Oct. & 27.36 & 29.56 & 30.06 & 29.00 & 26.76 & 28.86 & 29.20 & 28.27 \\
\hline & $10^{\text {th }}$ Nov. & 20.46 & 22.96 & 25.16 & 22.86 & 19.06 & 22.33 & 24.16 & 21.85 \\
\hline \multicolumn{2}{|c|}{ Mean } & 24.30 & 26.47 & 27.58 & 26.12 & 23.26 & 25.34 & 26.13 & 24.91 \\
\hline Mean for & $10^{\text {th }}$ Oct. & 25.18 & 27.68 & 28.28 & 27.05 & 24.50 & 25.43 & 25.85 & 25.26 \\
\hline Sowing & $25^{\text {th }}$ Oct. & 27.31 & 30.08 & 30.42 & 29.27 & 27.10 & 29.13 & 29.58 & 28.60 \\
\hline dates & $10^{\text {th }}$ Nov. & 20.95 & 23.61 & 25.90 & 23.48 & 19.63 & 22.18 & 24.10 & 21.97 \\
\hline \multicolumn{2}{|c|}{ Mean } & 24.48 & 27.12 & 28.20 & & 23.74 & 25.58 & 26.51 & \\
\hline \multicolumn{2}{|c|}{ L.S.D. at $5 \%$ for } & \multicolumn{3}{|c|}{$2016 / 17$} & \multicolumn{5}{|c|}{$2017 / 18$} \\
\hline \multicolumn{2}{|c|}{ Varieties (A) } & \multicolumn{3}{|c|}{ Sig. } & & \multicolumn{4}{|c|}{ Sig. } \\
\hline \multicolumn{2}{|c|}{ Sowing dates (B) } & \multicolumn{3}{|c|}{0.43} & & \multicolumn{4}{|c|}{0.08} \\
\hline \multicolumn{2}{|l|}{ Zinc $(\mathrm{C})$} & \multicolumn{3}{|c|}{0.51} & & \multicolumn{4}{|c|}{0.90} \\
\hline \multicolumn{2}{|l|}{$\mathrm{AX} \mathrm{B}$} & \multicolumn{3}{|c|}{ N.S } & & \multicolumn{4}{|c|}{ N.S } \\
\hline \multicolumn{2}{|l|}{ A X C } & \multicolumn{3}{|c|}{ N.S } & & \multicolumn{4}{|c|}{ N.S } \\
\hline \multicolumn{2}{|l|}{$\mathrm{B} X \mathrm{C}$} & \multicolumn{3}{|c|}{0.88} & & & N.s & & \\
\hline A X B X & $\mathrm{C}$ & & N.S & & & & N.s. & & \\
\hline
\end{tabular}


The desirable effect of sowing $25^{\text {th }}$ Oct. on protein percentage might be imputed to the suitable environmental conditions which play a vital role in activating establishment, growth and ripening of plants. These results are in the same trend with those found by Abido and Seadh (2014).

The presented results illustrate that, application of zinc to faba bean plants exerted a significant effect on seed protein content in the two seasons. In general, protein content in seeds were high when $60 \mathrm{ppm}$ was applied to faba bean plants compared to the control in the first and the second seasons. Inthis respect, high content of protein may be a direct result for high rates of photosynthesis with great efficiency. These results are in the same lines with this found by Saad (2015).

Protein content in seeds were significantly affected by the interaction between sowing dates and zinc in the first season only. Where the highest value of $30.42 \%$ were recorded for sowing faba bean Misr-1 variety in $25^{\text {th }}$ Oct. and foliar application with $60 \mathrm{ppm}$ zinc. Varieties x planting dates, varieties $\mathrm{x}$ zinc and the three way interaction were significant for this trait in both seasons.

\section{CONCLUSION}

Under conditions of the present work, the highest value of seed yield/fad.and quality of seeds were obtained from sowingfaba bean Misr-1 variety in $25^{\text {th }}$ Oct. and foliar with zinc concentration of either30 or $60 \mathrm{ppm}$.

\section{REFERENCES}

A.O.A.C. (1980). Official Methods of Analysis, $13^{\text {th }}$ Ed. Association of official Analytical Chemists, Washington, D. C.

Abd El-Monem, M. Sh.; I. I. Farghal and M. R. Sofy (2009). Response of broad bean and lupin plants to foliar treatment with boron and zinc. Aust. J. Basic \& Appl. Sci., 3 (3): 2226-2231.

Abido, W.A.E. and S.E. Seadh (2014). Rate of variations between field bean cultivars due to sowing dates and foliar spraying treatments. Science International, 2 (1): 1-12.

Ahmed, M.A. and H.M.H. El-Abagy (2007). Effect of bio- and mineral phosphorus fertilizer on the growth, productivity and nutritional value of some faba bean (Viciafaba,L.) cultivars in newly cultivated land. J. of Appl. Sci., Res., 3 (6): 408-420.

Alazaki, A.M. and Y. A. A. Al-Shebani (2012). Growth and yield components variation of two faba bean (Viciafaba L.) varieties as response to plantind dates and hill spacing. Minia J. of Agric. Res. \&Develop., 32 (3): 543-568.
Bakheit, B. R.; A. Y.Allam and Anaam. H. Galal (2001). Response of some faba bean cultivars to planting dates and population densities. Assiut J. of Agric. Sci., 32 (2): 85-101.

El-Banna, M.N.; F.I. Radwan; M.A.A. Nassar and Tahany F.M. El-Shshtawy (2009). Effect of plant density and bio-fertilization on the productivity and technological traits of some faba bean cultivars (Viciafaba, L.). J. Adv. Agric. Res. (Fac. Ag. Saba Basha) 14 (1): $47-$ 60.

El-Gizawy, N. Kh. B. and S. A. S. Mehasen (2009). Response of faba bean to bio, mineral phosphorus fertilizers and foliar application with zinc. World Appl. Sci. J., 6 (10): 13591365 .

Fageria, N. K. (2009). The use of nutrients in crop plants. Pesq.Agropec.Bras. 40: 1211-1215.

Freed, R.S.P.; S.P. Eisensmith; S. Goetez; D. Reicosky; V.W. Smail and P. Wolberge (1989). Users guide to MSTAT-C.A software program for the design, moorage regimentand analyses of agronomic research experiments Michigan State University, U.S.A.

Gomez, K. A. and A. A.Gomez (1984). Statistical Procedures for Agricultural Research $2^{\text {nd }}$ ed. John Wiley and Sons, Inc. New York.

Hassan, H. A. A. (2016). Response of some faba bean varieties to foliar spraying with salicylic acid and yeast. Ph.D. Thesis, Fac. Agric., Assiut, Al- Azhar Univ., Egypt.

Khalil, F. A.; K. A. A. El-Shaikh and R. E. El-Lithy (2004). Response of two faba bean cultivars to different levels of phosphorus and sulphur applications. Assiut J. of Agric. Sci. 35 (2): 289-309.

Mansour, M. M. (2014). Response of soybean plants to exogenously applied with ascorbic acid, zinc sulphate and paclobutrazol. Rep Opinion., 6 (11): 17-25.

Saad, A. M. (2015). Growth behavior and productivity of fababean (Faba vulgaris, L.) as affected by various promoting foliar applications. Middle East J. Appl. Sci., 5 (3): 804-811.

Sharaan, A. N.; Ekram A. Megawer; H. A. Saber and Z. A. Hemida (2004). Biological yield, its related growth criteria and chocolate - spot disease as influenced by cultivars, sowing dates and planting distances in faba bean. Fayoum J. Agric. Res. Dev., 18 (1): 110-125. 


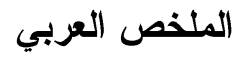

تأثير مواعيد الزراعة والرش الورقي بالزنك علي إنتاج وجودة صنفين من الفول البلاي أحمد يوسف مهاي وحجاجى عبد الحفيظ أحمد

قسم المحاصيل- كلية الزراعة- جامعة الأزهر - فرع أسيوط

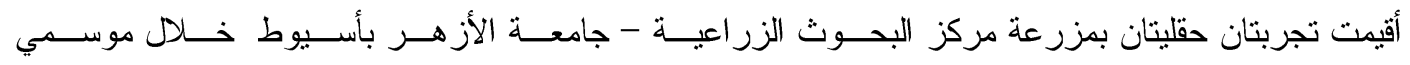


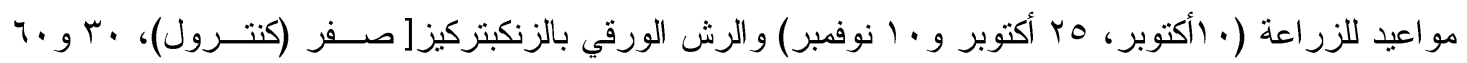

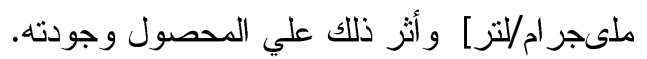

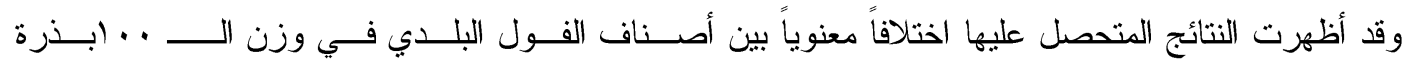

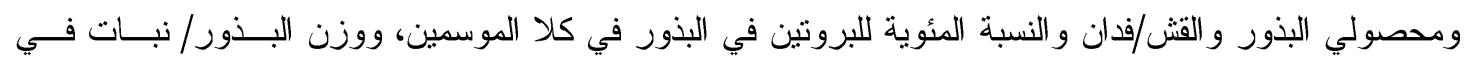

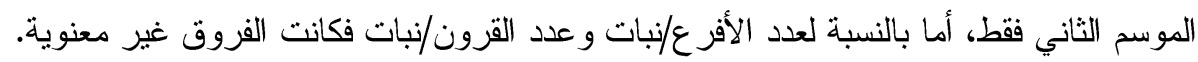

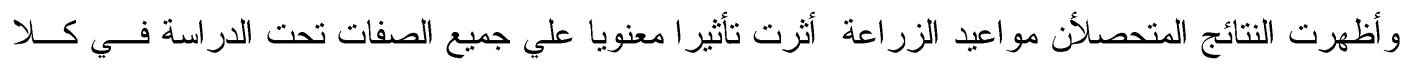

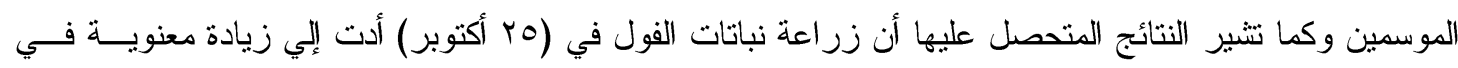

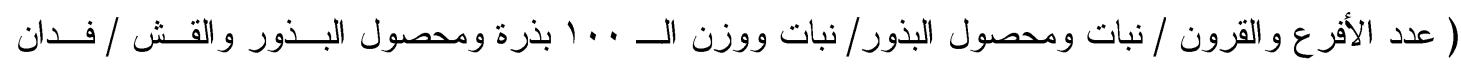

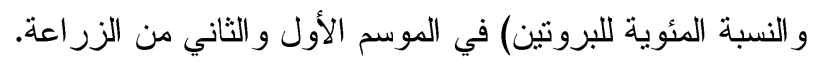

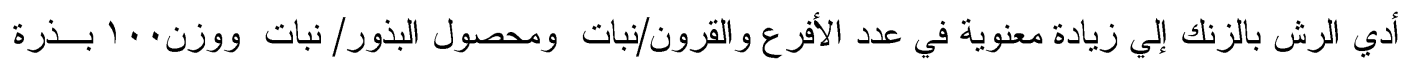
و محصول البذور والقش/فدان و النسبة المئوية للبروتين في البذور في كلادئ الموسمين.

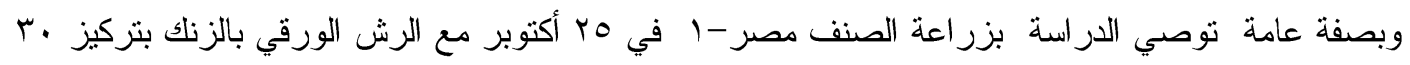

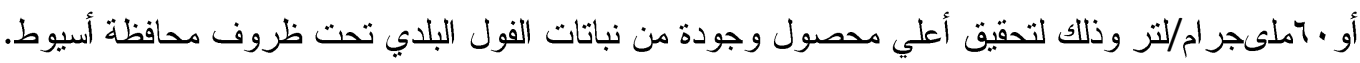

